\title{
Effect of Sowing Dates, Plant Density of Sesame and Intercropping on Yield and Yield Components of Cotton and Sesame
}

\author{
Moshira A .El-Shamy ${ }^{1}$, Mona A. M. El-Mansoury ${ }^{2}$ and Maha A. El-Bialy ${ }^{3}$
}

\begin{abstract}
A field trial was conducted at Sakha Agricultural Research Station, Kafr El - Sheikh Governorate $\left(31^{0} 07^{-} \mathrm{N}\right.$ Latitude and $30^{\circ} 57^{-} \mathrm{E}$ longitude with an elevation of about 6 mean sea level MSL), Egypt, during the two growing seasons of 2017 and 2018 to study the effect of sowing dates, plant density, and intercropping on yield and some yield attributes of cotton and sesame. Cotton (Gossypium barbadense $L$.) and sesame (Sesamum indicum) were sole cropped and intercropped at three sowing dates (April 15 th $\left(S_{1}\right)$, April $30{ }^{\text {th }}\left(S_{2}\right)$ and $\left.M{ }^{\text {th }}\left(S_{3}\right)\right)$ and two densities $\left(33 \%\left(D_{1}\right)\right.$ and $50 \%\left(D_{2}\right)$ of sole crop) with sesame. The experiment was laid out in randomized completely block design with split plot design with three replications. sowing date of sesame were randomized in main plots and plant density of sesame in subplots. The highest amount of applied water $(\mathrm{AW})$ and water consumptive use $(\mathrm{CU})$ were recorded under the first sowing date, while the highest productivity of irrigation water (PIW) and water productivity (WP) were recorded at the third sowing date and $33 \%$ density for sesame. Sowing dates had nonsignificant effect on all traits in cotton except seed yield /plant at the second season that was significant but seed yield /fed was significant of both two seasons, while, nonsignificant effect on all traits in sesame except seed yield /plant was significant at two seasons.
\end{abstract}

Plant densities were highly significant effect on all traits in cotton except plant height at two seasons. And boll weight at the first season, while, significant effect on all traits in sesame except no. of branches /plant that was in significant and seed yield /plant was significant at two seasons. The highest land equivalent ration (LER) were obtained 1.41, 1.40, respectively as mean of both two seasons. The highest mean net incomes were $(30120$ and 27688 L.E.) obtained from sowing date 3 (May15 ${ }^{\text {th }}$ ) and density $1(33 \%)$ of sesame in the first and second seasons, respectively.

Key Words: Cotton; Sesame; Planting densities; Sowing date; water relations, Land Equivalent Ratio.

\section{INTRODUCTION}

Cotton (Gossypium barbadense L. ) is the most important cash crop. In Egypt, more than one million rural families work in cotton production, over 850 thousand individuals participate in cotton manufacturing and trading and more than 1 million 250 persons serve indirectly in the cotton sector. The exports of cotton and textile products reached around US \$2400 million, while exports of raw lint cotton reached around US $\$ 170$ million in 2017/2018 due to the rise of world cotton prices. Egypt is considered one of the founders of the ICAC since 1939. Egypt seeks to face the challenges of cotton value chain and put intelligent and sustainable solutions for its cultivation, manufacturing and trading. Cotton productivity depends upon a large number of environmental factors such as crop and water management. An amount of irrigation water of cotton is ranged between 3400 and $4700 \mathrm{~m}^{3} / \mathrm{fed}$. To solve the problem of limitation of irrigation water resources a lot of ideas have been raised nowadays some of them were used in this present study such as cultivation on wide furrows (raised-beds technique) instead of cultivation on normal furrows (normal cultivation method) where raised-beds decreasing irrigation inlets, this technique tested on some field and vegetable crops and proved effective in increasing crop and water use efficiency, Raut et al., (2000) and Anonymous (2006).

Sesame (Sesame indium) is one of the major oil seed crops in the world and there are fifteen health and nutrition benefits of sesame seeds (15 Health and Nutrition Benefits of Sesame Seeds (healthline.com)). Abou-Kerisha et al (2008) showed that yields of all sesame varieties were decreased under condition of intercropping. Sesame Giza 32 variety surpassed the other varieties (Shandaweel 3 - and Toshka 1) in plant height, number of branches/plant, number of capsules/plant, seed yield/plant and seed yield/fed. the highest plant density (100\%) recorded the highest sesame seed yield/fed. where the increase were 46.93 and $13.50 \%$ in the first season, 2.46 and $8.71 \%$ in the

DOI: 10.21608/asejaiqjsae.2021.155572

${ }^{1}$ Crop Intensification Research Department, Field Crops Research Institute, A.R.C. Giza, Egypt.

${ }^{2}$ Water Requirements and Field Irrigation Res. Dept., Soils, Water and

Environment Research Institute, A.R.C., Giza, Egypt.

${ }^{3}$ Water Management Research Institute, National Water Research Center, P.O. Box 13621/5, Delta Barrage, Cairo, Egypt.

Received February 12, 2021, Accepted March 10, 2021 
second season and 25.86 and $11.19 \%$ in the combined data over the low and medium density treatments, respectively. Abdel-Galil and Abdel-Ghany (2014) indicated that the intercropping pattern 3 groundnut: 1 sesame recorded higher groundnut yield and its attributes than 2:2 pattern while the highest sesame yield and its attributes were obtained by 2:2 pattern.

Agricultural experts suggest that a way to improve productivity of cotton is intercropping system. For these reasons, Intercropping Cotton and sesame was done in Egypt as a conventional practice from years ago. Use of intercropping by smallholders is common in the rain fed areas all over the world (Ofuso-Amin, 2007). The advantages of intercropping over mono-cropping include soil conservation, lodging resistance, yield increment (Banik et al, 2006). When two crops are planted together, may occur intra and/or inter specific competition or facilitation between plants (Zhang et al, 2003). A number of indices such as Land Equivalent Ratio (LER), Relative Crowding Coefficient, Competitive Ratio, Actual Yield Loss and monetary advantages, have been proposed to describe competition and economic aspects of intercropping systems (Ghosh, 2004; Yilmaz, 2007) and Shahid (1997) reported a dominant effect of cotton having positive " $\mathrm{A}$ " value when grown in association with mung bean, mash bean and linseed. However, such indices have not been used for cotton and sesame to evaluate the competition among species in Egypt. Thus, the mains objectives of this current investigation were to investigate the effect of intercropping sesame (Sesame indium) and cotton (Gossypium barbadense L.) at different three sowing dates and two densities of sesame on growth, yield and its components of both plant species. Working on different intercropping patterns that could actually maximize resource efficiency would provide farmers opportunities for increasing the net incomes and maximum the use of their inputs.

\section{MATERIALS AND METHODS}

A field investigation was conducted at Sakha Agricultural Research Station, Kafr El- Sheikh governorate $\left(31^{\circ} 07^{-} \mathrm{N}\right.$ Latitude and $30^{\circ} 57^{-} \mathrm{E}$ longitude with an elevation of about 6 meters above the sea level), Egypt, during the summer, season 2017and 2018. The aim of this work was to study the effect of intercropping cotton with two densities of sesame $\left(33 \%\left(\mathrm{D}_{1}\right)\right.$ and $50 \%$ $\left(D_{2}\right)$ of sole crop) under three sowing dates in relation to yield and yield component of both crops. The cotton (the main crop) was grown on all ridges at (normal density). A split plot design with three replications was used. The main plots were occupied by three sesame sowing dates were (April $15^{\text {th }}\left(\mathrm{S}_{1}\right)$, April $30^{\text {th }}\left(\mathrm{S}_{2}\right)$ and May15 $\left.{ }^{\text {th }}\left(\mathrm{S}_{3}\right)\right)$ in the first and second seasons, respectively. and the sub plots were devoted to two sesame densities were 33\%, 50\% of solid crop .Cotton(c.v Giza 94) and sesame (c.v Shandaweel 3)were employed in this study seeds were received from Cotton Crop Research Inst., and oil Crops Research Dept., Field Crops Res. Inst., Agric. Res .Center. During $1^{\text {st }}$ and $2^{\text {nd }}$ seasons, cotton was sown on $31^{\text {th }}$ march and $1^{\text {st }}$ April, respectively. The area of each sub plot was $42 \mathrm{~m}^{2}(6 \mathrm{MSL}$ wide $\times 7 \mathrm{~m}$. long), containing five broadcasts. Cotton seed rates was $30 \mathrm{~kg}$ seed/fed was grown on two sides of all ridges $(100 \%)$ at $25 \mathrm{~cm}$ between hills $(2 \mathrm{pl} / \mathrm{hill})$, while sesame seed rate was $2 \mathrm{~kg} \mathrm{seed} / \mathrm{fed}$. was grown on broadcast $(50 \%)$ one alternative another broadcast, but $(33 \%)$ one alternative another two broadcast at $20 \mathrm{~cm}$. between hills ( $1 \mathrm{pl} / \mathrm{hill})$ Solid planting of cotton and sesame were sowing as recommended. Application of super phosphate fertilizer was added at a rate of $30 \mathrm{~kg} \mathrm{P}_{2} \mathrm{O}_{5}$ fed $^{-1}$ in the form of calcium super phosphate $\left(15.5 \% \mathrm{P}_{2} \mathrm{O}_{5}\right)$ before sowing and during soil preparation. Nitrogen fertilizer was applied at a rate of $60 \mathrm{~kg} \mathrm{~N}^{-1} \mathrm{fed}^{-1}$ was applied in two equal doses (i.e. at the first and second irrigation). Potassium fertilizer was applied at a rate of $24 \mathrm{~kg} \mathrm{~K}$ fed $^{-}$ ${ }^{1}$ was applied with the first dose for nitrogen fertilizer. Irrigation was added nine times during each growing season. The experiment was established on a clayey and well-drained soil.

Monthly participation, relative humidity and air temperature data recorded near the experimental location are given in table (1).

Some physical and chemical characteristics of the studied site were shown in Tables (2 and 3), of particle size distribution, soil bulk density, soil field capacity and permanent wilting point were determined according to (Klute, 1986) in Table (2). The studied chemical characteristics, in Table (3): Soil reaction $(\mathrm{pH})$ in 1:2.5 soil water suspension, Total soluble salts $\left(\mathrm{Ec}_{\mathrm{e}}\right)$ and soluble cations and anions were determined in soil paste extract by the standard methods as described by (Jackson, 1973).

\section{Data collection and calculations:}

\section{1-Applied water:}

Applied water included an irrigation water plus rainfall. Irrigation water was controlled and measured by rectangular weir. Irrigation water discharge was determined according to Michael, (1978) as follows:

\section{$Q=1.84$ LH $^{1.5}$}

Where: $\mathrm{Q}=$ water discharge, $\mathrm{m}^{3} \mathrm{sec}^{-1}, \mathrm{~L}=$ width of weir, $\mathrm{cm}$ and $\mathrm{H}=$ the head above weir crest, $\mathrm{cm}$. 


\section{2-Water consumptive use:}

To compute the actual consumed water of the growing plants. Soil moisture percentage was determined (on weight basis) before and after each irrigation as well as at harvesting. Water consumptive use by growing plants was calculated based on soil moisture depletion (SMD) according to Hansen et al, (1979).

$C U=S M D=\sum \frac{\theta 2-\theta 1}{100} * D b * D * 4200$

Where: $\mathrm{CU}=$ Water consumptive use in the effective root zone $(60 \mathrm{~cm}), \theta 2=$ Gravimetric soil moisture percentage after irrigation, $\Theta 1=$ Gravimetric soil moisture percentage before irrigation, $\mathrm{Db}=$ soil bulk density $\left(\mathrm{Mg} \mathrm{m}^{-3}\right)$ for depth, $\mathrm{D}=$ Soil layer depth $(60$ $\mathrm{cm}$ ), and $4200=$ feddan area in $\mathrm{m}^{2}$.

\section{3- Productivity of irrigation water (PIW)}

The productivity of irrigation water (PIW) is generally denied as crop yield $(\mathrm{kg})$ per cubic meter of applied water. It was calculated according to Ali et al., (2007).

$P I W=\frac{Y}{A W}$

Where: PIW = Productivity of irrigation water $\left(\mathrm{kg} \mathrm{m}^{-3}\right)$, $\mathrm{Y}=$ Yield $(\mathrm{kg})$ and $\mathrm{AW}=$ Applied water $\left(\mathrm{m}^{3}\right)$.

4- Water productivity (WP):
Water productivity (WP), is generally defined as crop yield $\left(\mathrm{kgfed}^{-1}\right.$ ) per cubic metre of water consumption. It was calculated according to Ali et al., (2007).

$W P=\frac{Y}{C u}$

Where: $\mathbf{W P}=$ Water productivity $\left(\mathrm{kg} \mathrm{m}^{-3}\right), \mathbf{Y}=$ Yield $(\mathrm{kg})$ and $\mathbf{C u}=$ Water consumptive use $\left(\mathrm{m}^{3}\right)$.

\section{5- Growth parameters}

At harvesting, ten plants were randomly chosen to determine the plant averages of

\section{a) Cotton were:}

1-Plant height, $\mathrm{cm}$.

2- No. of days to first flower appearance,

3-Boll weight (g), 4-Seed cotton yield /plant (g),

5- Seed yield /fed (kantar), 6-Lint cotton yield /plant,

7-Fiber length (mm), 8-Fiber Strength (g/tex),

9- Fiber Fineness (micromaire value),

10-Number of fruiting branches. 11- Lint \%.

b) Sesame were:

1-Plant height $(\mathrm{cm}) \quad$ 2- number of branches /plant

3- Number of capsules/plant 4-seed index (g)

5- Seed yield /plant (g), 6- seed yield /fed.

Table 1. Climatological data of Sakha region during the two seasons of study 2017 and 2018.

\begin{tabular}{|c|c|c|c|c|c|c|c|c|c|}
\hline \multicolumn{10}{|c|}{2017} \\
\hline \multirow[t]{2}{*}{ Month } & \multicolumn{3}{|c|}{$T\left(C^{0}\right)$} & \multicolumn{3}{|c|}{ RH (\%) } & \multirow{2}{*}{$\begin{array}{c}\mathrm{W}_{\mathrm{s}} \\
\mathrm{m} \mathrm{sec}^{-1}\end{array}$} & \multirow{2}{*}{$\begin{array}{c}\text { Pan Evap. } \\
\text { mm. }\end{array}$} & \multirow{2}{*}{$\begin{array}{l}\text { Rain, } \\
\text { Mm }\end{array}$} \\
\hline & Max & Min & Mean & Max & Min & Mean & & & \\
\hline Mar. & 22.5 & 18.0 & 20.2 & 84.9 & 60.3 & 72.6 & 0.97 & 2.97 & 0.00 \\
\hline April. & 26.5 & 21.6 & 24.1 & 79.4 & 50.8 & 65.1 & 1.03 & 4.54 & 0.00 \\
\hline May & 30.6 & 25.8 & 28.2 & 77.7 & 45.6 & 61.7 & 1.23 & 6.59 & 0.00 \\
\hline June & 32.5 & 28.1 & 30.3 & 80.1 & 51.4 & 65.8 & 1.19 & 7.10 & 0.00 \\
\hline July & 32.2 & 29.0 & 30.6 & 84.4 & 57.6 & 71.0 & 0.94 & 6.44 & 0.00 \\
\hline August & 33.9 & 28.3 & 31.1 & 85.9 & 55.3 & 70.6 & 0.81 & 6.04 & 0.00 \\
\hline Sep. & 32.5 & 25.9 & 29.2 & 86.3 & 50.3 & 68.3 & 0.99 & 5.37 & 0.00 \\
\hline Oct. & 28.7 & 24.0 & 26.4 & 81.1 & 54.7 & 67.9 & 0.85 & 3.26 & 10.6 \\
\hline \multicolumn{10}{|c|}{2018} \\
\hline Mar. & 25.5 & 16.6 & 21.1 & 89.3 & 48.4 & 68.8 & 0.54 & 4.24 & 0.00 \\
\hline April & 27.2 & 19.9 & 23.6 & 80.9 & 43.9 & 62.4 & 0.85 & 5.78 & 0.00 \\
\hline May & 31.2 & 23.9 & 27.6 & 75.6 & 43.3 & 59.4 & 1.10 & 6.34 & 0.00 \\
\hline June & 32.6 & 25.3 & 29.00 & 75.5 & 48.2 & 61.9 & 1.14 & 7.72 & 0.00 \\
\hline July & 34.2 & 25.4 & 29.8 & 82.5 & 51.0 & 66.8 & 1.03 & 7.90 & 0.00 \\
\hline August & 33.9 & 25.3 & 29.6 & 79.5 & 51.9 & 65.7 & 0.87 & 6.42 & 0.00 \\
\hline Sep. & 32.8 & 23.5 & 28.2 & 28.2 & 48.3 & 65.7 & 0.79 & 4.99 & 0.00 \\
\hline Oct. & 29.5 & 20.6 & 25.1 & 25.1 & 49.6 & 66.1 & 0.66 & 3.24 & 10.5 \\
\hline
\end{tabular}

Source: Sakha Meteorological Station. 
Table 2. The mean values of some physical characteristics of the studied site before cultivation through the two growing seasons 2017/18.

\begin{tabular}{|c|c|c|c|c|c|c|c|c|}
\hline \multirow{2}{*}{$\begin{array}{l}\text { Soil } \\
\text { Depth, } \\
\text { cm. }\end{array}$} & \multicolumn{3}{|c|}{ Particle Size Distribution } & \multirow{2}{*}{$\begin{array}{l}\text { Texture } \\
\text { classes }\end{array}$} & \multicolumn{3}{|c|}{$\begin{array}{l}\text { Soil moisture constants on } \\
\text { weight basses }\end{array}$} & \multirow{2}{*}{$\begin{array}{c}\text { Bulk } \\
\text { density } \\
\left(\mathrm{Mg} / \mathrm{m}^{3}\right)\end{array}$} \\
\hline & Sand\% & Silt \% & Clay \% & & F.C \% & P.W.P \% & AW \% & \\
\hline $0-20$ & 15.2 & 29.4 & 55.4 & Clayey & 43.7 & 23.8 & 19.9 & 1.14 \\
\hline $20-40$ & 21.9 & 30.8 & 47.3 & Clayey & 39.8 & 21.6 & 18.2 & 1.19 \\
\hline $40-60$ & 24.2 & 32.3 & 43.5 & Clayey & 38.3 & 20.8 & 17.5 & 1.21 \\
\hline Mean & 20.4 & 30.8 & 48.7 & Clayey & 40.6 & 22.1 & 18.5 & 1.18 \\
\hline
\end{tabular}

Where:- F.C $\%=$ Field capacity, P.W.P $\%=$ Permanent wilting point and AW $\%=$ Available water

Table 3. The mean values of some chemical characteristics of the studied site before cultivation through the two growing season 2017/18.

\begin{tabular}{lcccccccccc}
\hline Soil Depth, $\mathbf{c m}$ & \multirow{2}{*}{ Ec, $\mathbf{d S} / \mathbf{m}$} & \multirow{2}{*}{$\mathbf{P H}$} & \multicolumn{8}{c}{ Soluble ions meq/l } \\
\cline { 4 - 10 } & & & $\mathbf{C a}^{++}$ & $\mathbf{M g}^{++}$ & $\mathbf{N a}^{+}$ & $\mathbf{K}^{+}$ & $\mathbf{C O}^{--}$ & $\mathbf{H C O}^{--}$ & $\mathbf{C l}^{-}$ & $\mathbf{S O}_{4}^{--}$ \\
\hline $0-20$ & 2.37 & 8.44 & 7.11 & 3.89 & 12.55 & 0.26 & 0.00 & 4.55 & 10.50 & 8.76 \\
$20-40$ & 2.76 & 8.40 & 8.72 & 5.60 & 13.20 & 0.28 & 0.00 & 4.45 & 11.10 & 12.25 \\
$40-60$ & 3.59 & 8.37 & 11.05 & 7.89 & 16.80 & 0.29 & 0.00 & 4.40 & 11.50 & 20.13 \\
Mean & 2.91 & $\ldots$. & 8.96 & 5.79 & 14.18 & 0.28 & 0.00 & 4.47 & 11.03 & 13.71 \\
\hline
\end{tabular}

$\mathrm{PH}$ was measured in 1:2.5 soil water suspension and $\mathrm{SO}_{4}$ - calculated by the difference by soluble cations and anions.

\section{6- Land Equivalent Ratio (LER):}

The ratio of area needed under sole cropping to that of intercropping at the same management level to produce an equivalent yield was calculated according to Mead and Willey (1980) as follows:

$\mathrm{LER}=\left(\mathrm{Y}_{\mathrm{ab}} / \mathrm{Y}_{\mathrm{aa}}\right)+\left(\mathrm{Y}_{\mathrm{ba}} / \mathrm{Y}_{\mathrm{bb}}\right)$

Where, $\left(\mathrm{Y}_{\mathrm{aa}}\right)$ and $\left(\mathrm{Y}_{\mathrm{bb}}\right)$ are the sole crop yields of crops (a) and (b), respectively; while $\left(\mathrm{Y}_{\mathrm{ab}}\right)$ is the intercrop yield of crop a, and $\left(\mathrm{Y}_{\mathrm{ba}}\right)$ is the intercrop yield of crop b.

\section{7- Economic evaluation:}

It was calculated for each treatment in Egyptian pounds (L.E.) using the average market prices for both seasons. The average market prices were 2150 L.E. kentar $^{-1}$ for cotton, and 2500 L.E. $\mathrm{ardb}^{-1}$ for sesame yield.

\section{8- Statistical analysis:}

Data was statically analyzed according to Gomez and Gomez (1984). The experimental design was a split plot design with three replications.

\section{RESULTS AND DISCUSSIONS}

\section{1-Amount of seasonal applied water (AW) and consumptive use (CU):}

Results presented in Tables (4\&5) showed that, the overall mean values of $\mathrm{AW}$ and $\mathrm{CU}$ for cotton and sesame together were affected by sowing date and plant density treatments. These crops consider summer field crops. Seasonal amount of applied water for sesame was slightly affected by sowing date treatments. The highest seasonal values for IW were recorded under sowing date $\mathrm{S}_{1}$ (first sowing date) where the over mean value is $3637.42 \mathrm{~m}^{3} \mathrm{fed}^{-1}(86.61 \mathrm{~cm})$ in the mean two seasons, respectively. Meanwhile, the lowest seasonal values were recorded under $S_{3}$ and the values are $3540.3 \mathrm{~m}^{3}$ $\mathrm{fed}^{-1}(84.29 \mathrm{~cm})$ in the two growing seasons, respectively. Generally, the seasonal values for Wa can be descended in this order $S_{1}>S_{2}>S_{3}$.

Concerning, water consumptive use $\mathrm{CU}$ presented data in Table (5) indicated that the highest overall mean value for $\mathrm{CU}$ were recorded under $\mathrm{S}_{1}$ (first sowing date) and the values is $2495.04 \mathrm{~m}^{3} \mathrm{fed}^{-1}(59.41 \mathrm{~cm})$. Meanwhile, the lowest overall mean values were recorded under $\mathrm{S}_{3}$ treatment and the value is $2325.87 \mathrm{~m}^{3}$ $\mathrm{fed}^{-1}(55.38 \mathrm{~cm})$. Generally, the overall mean values of water consumptive use can be descended in order $S_{1}>$ $S_{2}>S_{3}$ and under plant density treatments $D_{2}>D_{1}$, respectively. Decreasing the values of $\mathrm{Cu}$ under $\mathrm{S}_{3}$ in comparison with $S_{1}$ and $S_{2}$ might be attributed to decreasing the amount of applied water and hence, forming weak plants with low vegetative cover. Therefore, decreasing amount of transpiration from plant surface. These results are in agreement with those reported by Chimanshette and Dhoble (1992), Meleha (2000), Raut et al. (2000) and Kassab, M. M. (2003). 
Table 4. Effect of sowing date and Plant Density on seasonal applied water (AW) for sesame intercropped on cotton in the two growing seasons.

\begin{tabular}{|c|c|c|c|c|c|c|c|}
\hline \multirow{3}{*}{ Sowing date } & \multirow{3}{*}{ Plant Density } & \multicolumn{6}{|c|}{$\mathbf{A W}$} \\
\hline & & \multicolumn{2}{|c|}{$\mathbf{1}^{\text {st }}$ growing season } & \multicolumn{2}{|c|}{$2^{\text {nd }}$ growing season } & \multicolumn{2}{|c|}{ Mean } \\
\hline & & $\mathrm{m}^{3}$ fed $^{-1}$ & $\mathbf{C m}$ & $\mathrm{m}^{3}$ fed $^{-1}$ & $\mathbf{C m}$ & m $^{3}$ fed $^{-1}$ & $\mathbf{C m}$ \\
\hline & $\mathrm{D}_{1}$ & 3647.50 & 86.85 & 3905.82 & 93.00 & 3776.66 & 89.92 \\
\hline $\mathrm{S}_{1}$ & $\mathrm{D}_{2}$ & 3647.50 & 86.85 & 3905.82 & 93.00 & 3776.66 & 89.92 \\
\hline \multirow[t]{2}{*}{ Mean } & & 3647.50 & 86.85 & 3905.82 & 93.00 & 3776.66 & 89.92 \\
\hline & $\mathrm{D}_{1}$ & 3501.24 & 83.36 & 3773.60 & 89.85 & 3637.42 & 86.61 \\
\hline $\mathrm{S}_{2}$ & $\mathrm{D}_{2}$ & 3501.24 & 83.36 & 3773.60 & 89.85 & 3637.42 & 86.61 \\
\hline \multirow[t]{2}{*}{ Mean } & & 3501.24 & 83.36 & 3773.60 & 89.85 & 3637.42 & 86.61 \\
\hline & $\mathrm{D}_{1}$ & 3449.27 & 82.18 & 3631.33 & 86.46 & 3540.30 & 84.29 \\
\hline $\mathrm{S}_{3}$ & $\mathrm{D}_{2}$ & 3449.27 & 82.18 & 3631.33 & 86.46 & 3540.30 & 84.29 \\
\hline Mean & & 3449.27 & 82.18 & 3631.33 & 86.46 & 3540.30 & 84.29 \\
\hline Cotton sole & & 3588.21 & 85.43 & 3872.07 & 92.19 & 3709.18 & 88.31 \\
\hline Sesame sole & & 2219.6 & 52.8 & 2374.5 & 56.54 & 2297.05 & 54.69 \\
\hline
\end{tabular}

$\mathrm{Wa}=$ water applied, $\mathrm{S}_{1}=$ first sowing date for sesame, $\mathrm{S}_{2}=$ second sowing date, $\mathrm{S}_{3}=$ third sowing date $\mathrm{D}_{1}=33 \%$, and $\mathrm{D}_{2}=50 \%$ density

Table 5. Effect of sowing date and Plant Density on seasonal consumptive use (Cu) for sesame intercropped on cotton in the two growing seasons.

\begin{tabular}{|c|c|c|c|c|c|c|c|}
\hline \multirow{3}{*}{ Sowing date } & \multirow{3}{*}{ Plant Density } & \multicolumn{6}{|c|}{$\mathbf{C U}$} \\
\hline & & \multicolumn{2}{|c|}{ 1. growing season } & \multicolumn{2}{|c|}{$2^{\text {nd }}$ growing season } & \multicolumn{2}{|c|}{ Mean } \\
\hline & & $\mathrm{m}^{3} \mathrm{fed}^{-1}$ & $\mathbf{C m}$ & $\mathrm{m}^{3}$ fed $^{-1}$ & cm & m $^{3}$ fed $^{-1}$ & $\mathbf{C m}$ \\
\hline & $\mathrm{D}_{1}$ & 2342.11 & 55.76 & 2402.59 & 57.20 & 2372.35 & 56.48 \\
\hline$S_{1}$ & $\mathrm{D}_{2}$ & 2586.95 & 61.59 & 2648.50 & 63.06 & 2617.73 & 62.33 \\
\hline \multirow[t]{2}{*}{ Mean } & & 2464.53 & 58.68 & 2525.55 & 60.32 & 2495.04 & 59.41 \\
\hline & $\mathrm{D}_{1}$ & 2255.88 & 53.71 & 2314.31 & 55.10 & 2285.10 & 54.41 \\
\hline $\mathrm{S}_{2}$ & $\mathrm{D}_{2}$ & 2400.72 & 57.16 & 2437.62 & 58.03 & 2419.17 & 57.60 \\
\hline \multirow[t]{2}{*}{ Mean } & & 2378.3 & 56.63 & 2375.97 & 56.57 & 2377.14 & 56.60 \\
\hline & $\mathrm{D}_{1}$ & 2180.0 & 51.90 & 2236.62 & 53.25 & 2208.31 & 52.58 \\
\hline $\mathrm{S}_{3}$ & $\mathrm{D}_{2}$ & 2414.90 & 57.49 & 2471.93 & 58.86 & 2443.40 & 58.18 \\
\hline Mean & & 2297.45 & 54.70 & 2354.28 & 56.05 & 2325.87 & 55.38 \\
\hline Cotton sole & & 2254.15 & 53.67 & 2380.67 & 56.68 & 2317.41 & 55.18 \\
\hline Sesame sole & & 1553.75 & 36.99 & 1665.27 & 39.65 & 1609.51 & 38.32 \\
\hline
\end{tabular}

$\mathrm{CU}=$ consumptive use, $\mathrm{S}_{1}=$ first sowing date for sesame, $\mathrm{S}_{2}=$ second sowing date, $\mathrm{S}_{3}=$ third sowing date $\mathrm{D}_{1}=33 \%$, and $\mathrm{D}_{2}=50 \%$ density

\section{2- Some irrigation efficiencies:}

Presented data in Table (6) indicated that the values of productivity of irrigation water (PIW) and water productivity (WP) were affected by both the two studied treatments (sowing date and plant density). Concerning, the effect of sowing dates treatments on PIW and WP, the highest mean values were recorded under $S_{3}$ in the first and second growing seasons and the values are 0.56 $\mathrm{kg} \mathrm{m}^{-3}$ for PIW and $0.86 \mathrm{~kg} \mathrm{~m}^{-3}$ for WP in the two growing seasons, respectively. Meanwhile, the lowest mean values were recorded under $S_{1}$ and the values are $0.53 \mathrm{~kg} \mathrm{~m}^{-3}$ for PIW and $0.80 \mathrm{~kg} \mathrm{~m}^{-3}$ for WP in the two growing seasons, respectively. Generally, the mean values for PIW and WP can be descended in order $\mathrm{D}_{2}>$ 
$\mathrm{D}_{1}$ in the first and second growing seasons under sowing dates treatments. Increasing the mean values of PIW and WP under treatment $S_{3}$ in comparison with other irrigation treatments $S_{1}$ and $S_{2}$ in the two growing seasons may be attributed to decreasing yield and increasing the amount of applied water and consumptive use under the conditions of irrigation treatment $S_{1}$ comparing with irrigation treatment $S_{3}$ which recorded the highest value for applied water and recorded the highest value for water consumptive use. Consequently, under these conditions the lowest mean values for PIW and WP were recorded. These findings are in the same line with those reported by Raut et al., (2000), Kassab, M. M. (2003) and Anonymous (2006).

Effect of sowing date and plant density treatments on Cotton

Presented data in Table (7) illustrated that the effect of sowing date and plant density on Plant height, no. of days to first flower appearance, boll weight of cotton in the two growing seasons. All traits were not significantly affected by sowing date and plant density in the two seasons while no. of days to first flower appearance was significant in two seasons but boll weight was significant in the second season. The tallest plants and the first flower appearance were found at the first sowing date and the second density of sesame in the two growing seasons. The results obtained are in conformity with the findings of Raghuwanshi et al., (1994), Ghosh (2004), Yilmaz(2007) and Dhima et al.(2007)

Table 6. Effect of sowing date and Plant Density on productivity of irrigation water (PIW) and water productivity (WP) for sesame intercropped on cotton in the two growing seasons.

\begin{tabular}{|c|c|c|c|c|c|c|c|}
\hline \multirow[b]{2}{*}{ Sowing date } & \multirow[b]{2}{*}{$\begin{array}{c}\text { Plant } \\
\text { Density }\end{array}$} & \multicolumn{3}{|c|}{ PIW $\left(\mathrm{kg} \mathrm{m}^{-3}\right)$} & \multicolumn{3}{|c|}{$\mathrm{WP}\left(\mathrm{kg} \mathrm{m}^{-3}\right)$} \\
\hline & & $\begin{array}{c}1^{\text {st }} \text { growing } \\
\text { season }\end{array}$ & $\begin{array}{c}2^{\text {nd }} \text { growing } \\
\text { season }\end{array}$ & Mean & $\begin{array}{c}1^{\text {st }} \text { growing } \\
\text { season }\end{array}$ & $\begin{array}{c}2^{\text {nd }} \text { growing } \\
\text { season }\end{array}$ & Mean \\
\hline & $\mathrm{D}_{1}$ & 0.56 & 0.52 & 0.54 & 0.87 & 0.85 & 0.86 \\
\hline$S_{1}$ & $\mathrm{D}_{2}$ & 0.52 & 0.49 & 0.51 & 0.74 & 0.73 & 0.74 \\
\hline \multirow[t]{2}{*}{ Mean } & & 0.54 & 0.51 & 0.53 & 0.81 & 0.79 & 0.80 \\
\hline & $\mathrm{D}_{1}$ & 0.58 & 0.54 & 0.56 & 0.90 & 0.89 & 0.90 \\
\hline $\mathrm{S}_{2}$ & $\mathrm{D}_{2}$ & 0.54 & 0.51 & 0.53 & 0.79 & 0.78 & 0.79 \\
\hline \multirow[t]{2}{*}{ Mean } & & 0.56 & 0.53 & 0.55 & 0.85 & 0.84 & 0.85 \\
\hline & $\mathrm{D}_{1}$ & 0.59 & 0.57 & 0.58 & 0.94 & 0.92 & 0.93 \\
\hline $\mathrm{S}_{3}$ & $\mathrm{D}_{2}$ & 0.55 & 0.53 & 0.54 & 0.79 & 0.78 & 0.79 \\
\hline Mean & & 0.57 & 0.55 & 0.56 & 0.87 & 0.85 & 0.86 \\
\hline Cotton sole & & 0.50 & 0.47 & 0.49 & 0.80 & 0.76 & 0.78 \\
\hline Sesame sole & & 0.27 & 0.27 & 0.27 & 0.39 & 0.39 & 0.39 \\
\hline
\end{tabular}

$\mathrm{PWa}=$ productivity of irrigation water, $\mathrm{WP}=$ water productivity, $\mathrm{S}_{1}=$ first sowing date for sesame, $\mathrm{S}_{2}=$ second sowing date, $\mathrm{S}_{3}=$ third sowing date $\mathrm{D}_{1}=33 \%$, and $\mathrm{D}_{2}=50 \%$ density
Presented data in Table (9) showed that the effect of sowing date on seed cotton yield/plant was not significantly and significant at the two seasons respectively. While, the effect of density was significant at two seasons. The effect of sowing date and density on seed yield /fed was significant, highly significant respectively at two seasons. Lint cotton yield /plant and fiber length (mm), the effect of sowing date for them were non-significant. But the effect of density for lint cotton yield /plant, fiber length $(\mathrm{mm})$ were significant and highly significant respectively at two seasons. The highest values in all traits at Table (9) were found at the third sowing date $\left(\mathrm{S}_{3}\right)$, first density $\left(\mathrm{D}_{1}\right)(33 \%)$ at the two growing seasons. The obtained results were harmony with those reported by Shahid (1997), Mohammad et al., (2001), Banik et al (2006), Dhima et al., (2007) and Iqbal et al .,(2007).

Table (9) showed that the effect of sowing date on fiber strength ( $\mathrm{g} / \mathrm{tex}$ ), fiber fineness (micromaire value), number of fruiting branches and lint were not significant in all pervious traits at two seasons. While the effect of density were significant in all traits except the first season of fiber strength and two seasons of lint \%.The highest values in all traits at table (10) were found at the third sowing date $\left(\mathrm{S}_{3}\right)$, first density $\left(\mathrm{D}_{1}\right)(33 \%)$ at the two growing seasons. There results agreed with those reported by Iqbal et al., (2007), Ofuso-Amin (2007) and yilmaz (2007). 
Table 7. Effect of sowing date and plant density for sesame with cotton on plant height $\mathrm{cm}$, no. of days to first flower appearance, boll weight $(\mathrm{g})$ of cotton in the two growing seasons.

\begin{tabular}{|c|c|c|c|c|c|c|c|}
\hline \multirow[t]{2}{*}{$\begin{array}{l}\text { Sowing } \\
\text { date }\end{array}$} & \multirow[t]{2}{*}{$\begin{array}{l}\text { Plant } \\
\text { Density }\end{array}$} & \multicolumn{2}{|c|}{ Plant height, cm } & \multicolumn{2}{|c|}{$\begin{array}{l}\text { No. of days to first } \\
\text { flower appearance }\end{array}$} & \multicolumn{2}{|c|}{$\begin{array}{l}\text { Boll weight } \\
\text { (g) }\end{array}$} \\
\hline & & $1^{\text {st }}$ season & $2^{\text {nd }}$ season & 1st season & $2 \frac{\text { nd }}{\text { season }}$ & $1^{\text {st }}$ season & $2^{\frac{\text { nd }}{2}}$ season \\
\hline \multirow[t]{2}{*}{$\mathrm{S}_{1}$} & $\mathrm{D}_{1}$ & 179.7 & 180.2 & 71.2 & 71.4 & 2.48 & 2.50 \\
\hline & D2 & 180.0 & 180.8 & 72.7 & 72.2 & 2.36 & 2.39 \\
\hline \multicolumn{2}{|c|}{ Mean $S_{1}$} & 179.9 & 180.5 & 72.0 & 71.8 & 2.42 & 2.45 \\
\hline & $\mathrm{D}_{1}$ & 178.0 & 178.7 & 71.9 & 72.0 & 2.53 & 2.56 \\
\hline $\mathrm{S}_{2}$ & $\mathrm{D}_{2}$ & 180.5 & 180.5 & 71.1 & 71.2 & 2.46 & 2.48 \\
\hline Mean $S_{2}$ & & 179 & 179.6 & 71.5 & 71.6 & 2.50 & 2.52 \\
\hline \multirow[t]{2}{*}{$\mathrm{S}_{3}$} & $\mathrm{D}_{1}$ & 177.3 & 177.9 & 71.8 & 71.9 & 2.58 & 2.60 \\
\hline & $\mathrm{D}_{2}$ & 179.7 & 179.8 & 71.4 & 71.6 & 2.37 & 2.39 \\
\hline \multicolumn{2}{|l|}{ Mean $S_{3}$} & 178.5 & 178.8 & 71.6 & 71.8 & 2.51 & 2.51 \\
\hline \multicolumn{2}{|c|}{ Mean S } & 179.13 & 179.37 & 71.7 & 71.7 & 2.5 & 2.5 \\
\hline \multicolumn{2}{|c|}{ L.S.D. $5 \%$ at $S$} & 1.435 & 1.724 & 0.232 & 0.846 & 0.009 & 0.177 \\
\hline \multicolumn{2}{|c|}{ F. Test } & Ns & Ns & Ns & Ns & Ns & Ns \\
\hline \multicolumn{2}{|c|}{ L.S.D. $5 \%$ at D } & 2.390 & 2.320 & 0.841 & 0.634 & 0.180 & 0.120 \\
\hline \multicolumn{2}{|c|}{ F. Test } & Ns & Ns & $*$ & $*$ & Ns & $*$ \\
\hline \multicolumn{2}{|c|}{$\mathrm{S} * \mathrm{D}$} & Ns & Ns & Ns & $\mathrm{Ns}$ & Ns & Ns \\
\hline \multicolumn{2}{|c|}{ Cotton sole } & 186.54 & 188.22 & 73.31 & 75.11 & 2.95 & 3.02 \\
\hline
\end{tabular}

$\mathrm{S}_{1}=$ first sowing date for sesame, $\mathrm{S}_{2}=$ second sowing date, $\mathrm{S}_{3}=$ third sowing date $\mathrm{D}_{1}=33 \%, \mathrm{D}_{2}=50 \%$ density $*$ and $* *$ represent significant differences between means at 0.05 and 0.01 level of probability, respectively; NS, non - significant. Each value is mean \pm S.D.

Table 8. Effect of sowing date and density for sesame with cotton on seed cotton yield /plant(g), seed yield /fed (kantar), lint cotton yield /plant, fiber length $(\mathrm{mm})$ of cotton in the two growing seasons.

\begin{tabular}{|c|c|c|c|c|c|c|c|c|c|}
\hline \multirow{2}{*}{$\begin{array}{l}\text { Sowing } \\
\text { date }\end{array}$} & \multirow{2}{*}{$\begin{array}{c}\text { Plant } \\
\text { Density }\end{array}$} & \multicolumn{2}{|c|}{$\begin{array}{c}\text { Seed yield /plant } \\
(\mathrm{g})\end{array}$} & \multicolumn{2}{|c|}{$\begin{array}{c}\text { Seed yield /fed } \\
\text { (kantar) }\end{array}$} & \multicolumn{2}{|c|}{ Lint yield /plant } & \multicolumn{2}{|c|}{$\begin{array}{c}\text { Fiber length } \\
(\mathrm{mm})\end{array}$} \\
\hline & & $\begin{array}{c}1^{\text {st }} \\
\text { season }\end{array}$ & $\begin{array}{c}2 \text { nd } \\
\text { season }\end{array}$ & $\begin{array}{c}1 \text { st } \\
\text { season }\end{array}$ & $\begin{array}{c}\text { 2 } \\
\text { season } \\
\end{array}$ & $\begin{array}{c}11^{\text {st }} \\
\text { season }\end{array}$ & $\begin{array}{c}2 \frac{\text { nd }}{\text { season }} \\
\text { seas }\end{array}$ & $\begin{array}{c}11^{\text {st }} \\
\text { season }\end{array}$ & $\begin{array}{c}2 \text { nd } \\
\text { season }\end{array}$ \\
\hline & $\mathrm{D}_{1}$ & 194.1 & 194.2 & 11.17 & 11.24 & 79.2 & 79.3 & 32.1 & 32.12 \\
\hline $\mathrm{S}_{1}$ & D2 & 192.0 & 193.0 & 10.48 & 10.53 & 79.0 & 79.1 & 31.2 & 31.3 \\
\hline \multirow[t]{2}{*}{ Mean $S_{1}$} & & 193.5 & 193.6 & 10.82 & 10.89 & 79.1 & 79.2 & 31.65 & 31.71 \\
\hline & $\mathrm{D}_{1}$ & 195.0 & 195.2 & 11.18 & 11.28 & 79.2 & 79.3 & 32.1 & 32.1 \\
\hline $\mathrm{S}_{2}$ & $\mathrm{D}_{2}$ & 193.4 & 193.5 & 10.42 & 10.48 & 78.6 & 78.9 & 30.6 & 30.7 \\
\hline \multirow[t]{2}{*}{ Mean $S_{2}$} & & 194.2 & 194.35 & 10.80 & 10.88 & 78.9 & 79.1 & 31.4 & 31.4 \\
\hline & $\mathrm{D}_{1}$ & 196.1 & 196.3 & 11.36 & 11.47 & 79.4 & 79.4 & 32.3 & 32.2 \\
\hline $\mathrm{S}_{3}$ & $\mathrm{D}_{2}$ & 194.0 & 194.2 & 10.48 & 10.56 & 79.1 & 79.1 & 31.2 & 31.3 \\
\hline \multicolumn{2}{|l|}{ Mean $\mathrm{S}_{3}$} & 195.05 & 195.3 & 10.92 & 11.02 & 79.3 & 79.3 & 31.8 & 31.8 \\
\hline \multicolumn{2}{|c|}{ Mean S } & 194.3 & 194.4 & 10.85 & 10.93 & 79.1 & 79.1 & 31.6 & 31.6 \\
\hline \multicolumn{2}{|c|}{ L.S.D. $5 \%$ at $S$} & 1.290 & 1.098 & 0.428 & 0.415 & 0.684 & 0.534 & 1.070 & 0.608 \\
\hline \multicolumn{2}{|c|}{ F. Test } & Ns & $*$ & $*$ & $*$ & Ns & Ns & Ns & Ns \\
\hline \multicolumn{2}{|c|}{ L.S.D. $5 \%$ at D } & 1.199 & 1.228 & 0.0102 & 0.129 & 0.311 & 0.291 & 0.601 & 0.380 \\
\hline \multicolumn{2}{|c|}{ F. Test } & $*$ & $*$ & $* *$ & $* *$ & $*$ & $*$ & $* *$ & $* *$ \\
\hline \multicolumn{2}{|c|}{$\mathrm{S} * \mathrm{D}$} & Ns & Ns & $* *$ & $* *$ & Ns & Ns & Ns & Ns \\
\hline \multicolumn{2}{|c|}{ Cotton sole } & 193.2 & 193.4 & 11.51 & 11.53 & 79.2 & 79.4 & 34.36 & 34.48 \\
\hline
\end{tabular}

$\mathrm{S}_{1}=$ first sowing date for sesame, $\mathrm{S}_{2}=$ second sowing date, $\mathrm{S}_{3}=$ third sowing date $\mathrm{D}_{1}=33 \%, \mathrm{D}_{2}=50 \%$ density

$*$ and $* *$ represent significant differences between means at 0.05 and 0.01 level of probability, respectively; NS, non-significant.

Each value is mean \pm S.D. 
Table 9. Effect of sowing date and density for sesame with cotton on fiber strength(g/tex), fiber fineness (micromaire value). no. of fruiting branches and lint \% of cotton in the two growing seasons.

\begin{tabular}{|c|c|c|c|c|c|c|c|c|c|}
\hline \multirow[t]{2}{*}{$\begin{array}{l}\text { Sowing } \\
\text { date }\end{array}$} & \multirow[t]{2}{*}{$\begin{array}{l}\text { Plant } \\
\text { Density }\end{array}$} & \multicolumn{2}{|c|}{$\begin{array}{l}\text { Fiber Strength } \\
(\mathrm{g} / \mathrm{tex})\end{array}$} & \multicolumn{2}{|c|}{$\begin{array}{c}\text { Fiber Fineness } \\
\text { (micromaire value) }\end{array}$} & \multicolumn{2}{|c|}{$\begin{array}{l}\text { No. of fruiting } \\
\text { branches. }\end{array}$} & \multicolumn{2}{|c|}{ Lint \% } \\
\hline & & $\begin{array}{c}1^{\text {st }} \\
\text { season }\end{array}$ & $\begin{array}{c}2^{\text {nd }} \\
\text { season }\end{array}$ & $\begin{array}{c}1^{\text {st }} \\
\text { season }\end{array}$ & $\begin{array}{c}2^{\text {nd }} \\
\text { season }\end{array}$ & $\begin{array}{c}1^{\text {st }} \\
\text { season }\end{array}$ & $\begin{array}{c}2^{\text {nd }} \\
\text { season }\end{array}$ & $\begin{array}{c}1^{\text {st }} \\
\text { season }\end{array}$ & $\begin{array}{c}2^{\text {nd }} \\
\text { season }\end{array}$ \\
\hline & $\mathrm{D}_{1}$ & 39.32 & 39.36 & 3.98 & 4.10 & 7.87 & 8.03 & 40.75 & 40.79 \\
\hline $\mathrm{S}_{1}$ & D2 & 39.19 & 39.20 & 3.93 & 4.01 & 7.53 & 7.70 & 40.43 & 40.50 \\
\hline \multirow[t]{2}{*}{ Mean $S_{1}$} & & 39.3 & 39.3 & 3.96 & 4.06 & 7.7 & 7.9 & 40.6 & 40.7 \\
\hline & $\mathrm{D}_{1}$ & 39.33 & 39.37 & 4.01 & 4.12 & 7.43 & 7.73 & 40.75 & 40.78 \\
\hline $\mathrm{S}_{2}$ & $\mathrm{D}_{2}$ & 39.22 & 39.25 & 3.95 & 3.98 & 7.50 & 7.67 & 40.70 & 40.71 \\
\hline \multirow[t]{2}{*}{ Mean $S_{2}$} & & 39.28 & 39.32 & 4.01 & 4.07 & 7.5 & 7.74 & 40.73 & 40.7 \\
\hline & $\mathrm{D}_{1}$ & 39.34 & 39.38 & 4.06 & 4.15 & 7.97 & 8.23 & 41.02 & 40.90 \\
\hline $\mathrm{S}_{3}$ & $\mathrm{D}_{2}$ & 39.27 & 39.30 & 3.95 & 3.98 & 7.57 & 7.73 & 40.86 & 40.95 \\
\hline \multicolumn{2}{|l|}{ Mean $\mathrm{S}_{3}$} & 39.3 & 39.34 & 3.98 & 4.05 & 7.77 & 7.98 & 40.94 & 40.9 \\
\hline \multicolumn{2}{|c|}{ Mean S } & 39.3 & 39.4 & 3.98 & 4.06 & 7.7 & 7.87 & 40.7 & 41.3 \\
\hline \multicolumn{2}{|c|}{ L.S.D. $5 \%$ at $S$} & 0.174 & 0.097 & 0.114 & 0.104 & 0.336 & 0.343 & 0.349 & 0.063 \\
\hline \multicolumn{2}{|c|}{ F. Test } & Ns & Ns & Ns & Ns & Ns & Ns & Ns & Ns \\
\hline \multicolumn{2}{|c|}{ L.S.D. $5 \%$ at D } & 0.163 & 0.112 & 0.063 & 0.112 & 0.203 & 0.256 & 0.099 & 0.338 \\
\hline \multicolumn{2}{|c|}{ F. Test } & Ns & $*$ & $*$ & $*$ & $*$ & $*$ & Ns & Ns \\
\hline \multicolumn{2}{|c|}{$\mathrm{S} * \mathrm{D}$} & Ns & Ns & Ns & Ns & Ns & Ns & Ns & Ns \\
\hline \multicolumn{2}{|c|}{ Cotton sole } & 39.34 & 39.37 & 4.22 & 4.35 & 7.92 & 8.11 & 40.51 & 40.63 \\
\hline
\end{tabular}

$\mathrm{S}_{1}=$ first sowing date for sesame, $\mathrm{S}_{2}=$ second sowing date, $\mathrm{S}_{3}=$ third sowing date $\mathrm{D} 1=33 \%$, D2 =50\% density

$*$ and ** represent significant differences between means at 0.05 and 0.01 level of probability, respectively; NS, non-significant.

Each value is mean \pm S.D.

\section{Sesame}

Data in Table (10) showed that the effect of sowing date on plant height, number of branches /plant and number of capsules/ plant of sesame were not significant in all traits in the two growing seasons. While, the effect of density were highly significant in plant height and number of capsules/ plant. But not significant in number of branches /plant in the two growing seasons. These results are in accordance with those obtained by Toaima et al (2004), Bhatti et al.,(2006), Rahnama and Bakhshandel (2006) and Iqbal et al,.(2007).

Table (11) presented that the effect of sowing date on seed index $(\mathrm{g})$, seed yield /plant $(\mathrm{g})$ and seed yield /fed were non-significant except seed yield /plant was significant. While the effect of density were highly significant in seed index and seed yield /plant except seed yield / fed. The highest values in all traits at table (12) were found at the first sowing date $\left(S_{1}\right)$,first density $\left(D_{1}\right)(33 \%)$ except plant height was found at the first sowing date $\left(S_{1}\right)$ and second density $\left(\mathrm{D}_{2}\right)(50 \%)$ at the two growing seasons. These results are in a great harmony with those reported by Badran (2002), Bhatti et al., (2006), El-Sawy et al (2006), Rahnama and Bakhshandel (2006).

\section{Land Equivalent Ratio (LER) and Gross Return (L.E., fed $^{-1}$ )}

The land equivalent ratio is a method used to calculate the effectiveness of intercropping systems. It is the most widely used index for measuring the advantages of intercropping systems on the combined yield of both crops. It is defined as the relative land area under sole crops required producing yields achieved in intercropping. Data in Table (13) recorded that, the land equivalent ratio values were affected by the sowing date and density for sesame in the two growing seasons. Concerning the effect of sowing date on land equivalent ratio, the highest values in the two growing seasons were shown under the third sowing date treatment $\left(\mathrm{S}_{3}\right)$ under the first density $\left(D_{1}\right)$. Whereas, the lowest values were recorded under the second sowing date treatment $\left(\mathrm{S}_{2}\right)$, under the second sesame density $\left(\mathrm{D}_{2}\right)(50 \%)$. These results are in harmony with those obtained by AbouKhadra et al. (2013), Toaima et al (2004) and ElSawy et al (2006) they concluded that LER values were high at any intercropping systems. 
Sowing date and density for sesame affected gross return, for sowing date the highest values were recorded under sowing date treatment $\left(\mathrm{S}_{3}\right)$ and the values are 31240 and 28712 (L.E. fed $^{-1}$ ) at the same time, the lowest values were showed under sowing date treatment $S_{2}$ and density $D_{2}$ the values are 29078 and 26732 the first and second growing seasons, respectively. On the other hand, density showed an effect on gross return under the overall sowing date for sesame in the two growing seasons. These results were in line with were reported by Mahdy and El-Said.(2015).

Table 10. Effect of sowing date and density for sesame with cotton on plant height, no. of branches /plant and no. of capsules/ plant of sesame in the two growing seasons.

\begin{tabular}{llcccccc}
\hline Sowing date & Plant & \multicolumn{2}{c}{ Plant height, cm } & \multicolumn{2}{c}{ No. of branches / plant } & \multicolumn{2}{c}{ No. of capsules / plant } \\
\cline { 2 - 7 } & Density & $\mathbf{1}^{\text {st }}$ season & $\mathbf{2}^{\text {nd }}$ season & $\mathbf{1}^{\text {st }}$ season & $\mathbf{2}^{\text {nd }}$ season & $\mathbf{1}^{\text {st }}$ season & $\mathbf{2}^{\text {nd }}$ season \\
\hline & $\mathrm{D}_{1}$ & 96.6 & 99.01 & 2.29 & 2.35 & 108.53 & 108.65 \\
$\mathrm{~S}_{1}$ & $\mathrm{D} 2$ & 114.1 & 114.53 & 1.97 & 2.04 & 105.87 & 106.15 \\
Mean $\mathrm{S}_{1}$ & & 105.85 & 106.77 & 2.115 & 2.195 & 107.2 & 107.4 \\
& $\mathrm{D}_{1}$ & 97.6 & 99.01 & 2.26 & 2.33 & 108.13 & 108.35 \\
$\mathrm{~S}_{2}$ & $\mathrm{D}_{2}$ & 113.5 & 114.34 & 1.90 & 1.90 & 106.48 & 106.67 \\
Mean S & & 105.85 & 106.77 & 2.095 & 2.115 & 107.31 & 107.51 \\
& & 97.7 & 97.75 & 2.25 & 2.31 & 108.01 & 108.07 \\
$\mathrm{~S}_{3}$ & $\mathrm{D}_{1}$ & 112.4 & 113.39 & 1.85 & 1.91 & 105.32 & 105.54 \\
Mean S S & $\mathrm{D}_{2}$ & 104.55 & 105.57 & 2.05 & 2.11 & 106.76 & 106.86 \\
Mean S & & 105.42 & 106.37 & 2.087 & 2.14 & 107.06 & 107.26 \\
L.S.D. 5\% at S & & 3.108 & 3.401 & 0.150 & 0.093 & 1.662 & 1.830 \\
F. Test & & $\mathrm{Ns}$ & $\mathrm{Ns}$ & $\mathrm{Ns}$ & $\mathrm{Ns}$ & $\mathrm{Ns}$ & $\mathrm{Ns}$ \\
L.S.D. 5\% at D & & 1.675 & 1.520 & 0.409 & 0.412 & 0.909 & 0.857 \\
F. Test & & $* *$ & $* *$ & $\mathrm{Ns}$ & $\mathrm{Ns}$ & $* *$ & $* *$ \\
S $*$ D & & $\mathrm{Ns}$ & $\mathrm{Ns}$ & $\mathrm{Ns}$ & $\mathrm{Ns}$ & $\mathrm{Ns}$ & $\mathrm{Ns}$ \\
Sesame sole & & 116.21 & 116.36 & 2.32 & 2.44 & 109.48 & 109.56 \\
\hline
\end{tabular}

$\mathrm{S} 1=$ first sowing date for sesame, $\mathrm{S}_{2}=$ second sowing date, $\mathrm{S}_{3}=$ third sowing date $\mathrm{D}_{1}=33 \%, \mathrm{D}_{2}=50 \%$ density

$*$ and $* *$ represent significant differences between means at 0.05 and 0.01 level of probability, respectively; NS, non-significant.

Each value is mean \pm S.D.

Table 11. Effect of sowing date and plant density for sesame with cotton on seed index (g), seed yield /plant (g) and seed yield /fed of sesame in the two growing seasons.

\begin{tabular}{|c|c|c|c|c|c|c|c|}
\hline \multirow[t]{2}{*}{ Sowing date } & \multirow{2}{*}{$\begin{array}{l}\text { Plant } \\
\text { Density }\end{array}$} & \multicolumn{2}{|c|}{ Seed index $(\mathrm{g})$} & \multicolumn{2}{|c|}{ Seed yield / plant (g) } & \multicolumn{2}{|c|}{ Seed yield / fed (ardab) } \\
\hline & & 1st season & 2 $\frac{\text { nd }}{\text { season }}$ & 1st season & 2 $\frac{\text { nd }}{\text { season }}$ & 1st season & 2d-nseason \\
\hline & $\mathrm{D}_{1}$ & 4.45 & 4.55 & 13.90 & 14.12 & 2.28 & 2.34 \\
\hline $\mathrm{S}_{1}$ & D2 & 4.18 & 4.21 & 12.81 & 12.94 & 2.19 & 2.25 \\
\hline \multirow[t]{2}{*}{ Mean $S_{1}$} & & 4.31 & 4.38 & 13.56 & 13.69 & 2.24 & 2.30 \\
\hline & $\mathrm{D}_{1}$ & 4.45 & 4.54 & 13.72 & 13.83 & 2.26 & 2.33 \\
\hline $\mathrm{S}_{2}$ & $\mathrm{D}_{2}$ & 3.93 & 4.01 & 12.56 & 12.67 & 2.13 & 2.22 \\
\hline \multirow{2}{*}{ Mean $\mathrm{S}_{2}$} & & 4.19 & 4.28 & 13.36 & 13.53 & 2.20 & 2.28 \\
\hline & $\mathrm{D}_{1}$ & 4.42 & 4.51 & 13.09 & 13.23 & 2.14 & 2.23 \\
\hline $\mathrm{S}_{3}$ & $\mathrm{D}_{2}$ & 3.92 & 3.97 & 13.02 & 13.15 & 2.11 & 2.19 \\
\hline Mean $\mathrm{S}_{3}$ & & 4.17 & 4.24 & 13.14 & 13.26 & 2.21 & 2.21 \\
\hline Mean S & & 4.22 & 4.30 & 13.35 & 13.49 & 2.19 & 2.26 \\
\hline L.S.D. $5 \%$ at $\mathrm{S}$ & & 0.312 & 0.254 & 0.227 & 0.258 & 0242 & 0.250 \\
\hline F. Test & & Ns & Ns & $*$ & $*$ & $\mathrm{Ns}$ & Ns \\
\hline L.S.D. $5 \%$ at D & & 0.298 & 0.452 & 0.620 & 0.659 & 0.090 & 0.077 \\
\hline F. Test & & $* *$ & $* *$ & $* *$ & $* *$ & Ns & Ns \\
\hline $\mathrm{S} * \mathrm{D}$ & & Ns & Ns & Ns & $\mathrm{Ns}$ & Ns & Ns \\
\hline Sesame sole & & 4.63 & 4.75 & 15.22 & 16.34 & 5.00 & 5.40 \\
\hline
\end{tabular}

$\mathrm{S}_{1}=$ first sowing date for sesame, $\mathrm{S}_{2}=$ second sowing date, $\mathrm{S}_{3}=$ third sowing date $\mathrm{D}_{1}=33 \%, \mathrm{D}_{2}=50 \%$ density

$*$ and $* *$ represent significant differences between means at 0.05 and 0.01 level of probability, respectively; NS, non-significant.

Each value is mean \pm S.D. 
Table 12. Effect of sowing date and Plant Density on total yield $\left(\mathrm{kg} \mathrm{fed}^{-1}\right)$ of cotton and sesame in the two growing seasons.

\begin{tabular}{llcccccc}
\hline & Plant & \multicolumn{3}{c}{$\mathbf{1}^{\text {st }}$ growing season } & \multicolumn{3}{c}{$\mathbf{2}^{\text {nd }}$ growing season } \\
\cline { 2 - 7 } Sowing date & Density & Cotton & Sesame & Total & Cotton & Sesame & Total \\
\hline \multirow{3}{*}{$\mathrm{S}_{1}$} & $\mathrm{D}_{1}$ & 1753.7 & 273.6 & 2027.3 & 1764.7 & 280.8 & 2045.5 \\
Mean & $\mathrm{D}_{2}$ & 1645.4 & 262.8 & 1908.2 & 1653.2 & 270.0 & 1923.2 \\
& & 1699.6 & 268.2 & 1967.8 & 1709.0 & 275.4 & 1984.4 \\
$\mathrm{~S}_{2}$ & $\mathrm{D}_{1}$ & 1755.3 & 271.2 & 2026.5 & 1771.0 & 279.6 & 2050.6 \\
Mean & $\mathrm{D}_{2}$ & 1635.9 & 255.6 & 1891.5 & 1645.4 & 266.4 & 1911.8 \\
& & 1695.6 & 263.4 & 1959.0 & 1708.2 & 273.0 & 1981.2 \\
$\mathrm{~S}_{3}$ & $\mathrm{D}_{1}$ & 1783.5 & 256.8 & 2040.3 & 1800.8 & 267.6 & 2068.4 \\
Mean & $\mathrm{D}_{2}$ & 1645.4 & 253.2 & 1898.6 & 1657.9 & 265.2 & 1923.7 \\
Cotton sole & & 1714.5 & 255.0 & 1969.5 & 1729.4 & 266.4 & 1994.0 \\
Sesame sole & & 1807.1 & ---- & 1807.1 & 1810.2 & ---- & 1810.2 \\
\hline
\end{tabular}

$\mathrm{S}_{1}=$ first sowing date for sesame, $\mathrm{S}_{2}=$ second sowing date, $\mathrm{S}_{3}=$ third sowing date $\mathrm{D}_{1}=33 \%$, and $\mathrm{D}_{2}=50 \%$ density.

Table 13. Effect of sowing date and density for sesame with cotton on the land equivalent ratio (LER) and gross return (L.E., fed. ${ }^{-1}$ ) in the two growing seasons

\begin{tabular}{|c|c|c|c|c|c|}
\hline \multirow[t]{2}{*}{ Sowing date } & \multirow{2}{*}{$\begin{array}{c}\text { Plant } \\
\text { Density }\end{array}$} & \multicolumn{2}{|c|}{ Land equivalent ratio } & \multicolumn{2}{|c|}{ Gross return (L.E. $\quad$ fed $\left.^{-1}\right)$} \\
\hline & & 1st $^{\text {st }}$ season & $2^{\text {ndd }}$ season & 1 $^{\text {st }}$ season & 2nd season \\
\hline & $\mathrm{D}_{1}$ & 1.45 & 1.39 & 31163 & 28564 \\
\hline$S_{1}$ & D2 & 1.33 & 1.31 & 29360 & 26910 \\
\hline \multirow[t]{2}{*}{ Mean $S_{1}$} & & 1.39 & 1.35 & 30262 & 27760 \\
\hline & $D_{1}$ & 1.41 & 1.39 & 31138 & 28618 \\
\hline $\mathrm{S}_{2}$ & $\mathrm{D}_{2}$ & 1.36 & 1.30 & 29078 & 26732 \\
\hline \multirow[t]{2}{*}{ Mean $\mathrm{S}_{2}$} & & 1.39 & 1.35 & 30120 & 27688 \\
\hline & $\mathrm{D}_{1}$ & 1.44 & 1.38 & 31240 & 28712 \\
\hline $\mathrm{S}_{3}$ & $\mathrm{D}_{2}$ & 1.32 & 1.30 & 29168 & 26814 \\
\hline Mean $\mathrm{S}_{3}$ & & 1.38 & 1.34 & 30420 & 27786 \\
\hline
\end{tabular}

$\mathrm{S}_{1}=$ first sowing date for sesame, $\mathrm{S}_{2}=$ second sowing date, $\mathrm{S}_{3}=$ third sowing date $\mathrm{D}_{1}=33 \%, \mathrm{D}_{2}=50 \%$ density sesame sole $=12000,14140$ (LE) cotton sole $=23.690,20900$ (LE).

\section{REFERENCES}

Abdel - Galil, A. M. and R. E. Abdel - Chany. 2014. Effect of groundnut - sesame intercropping and nitrogen fertilizer on yield, yield components and infection of root - rot and wilt diseases. Inter. J. of Plant and Soil Sic. 3 No. (6): 623 -643 .

AbouKhadra, S.H., A.E.B. Shaimaa, E.A.T. Salah and E.E.E. Dina. 2013.Effect of intercropping wheat with sugar beet on their productivity and land use. J. Agric. Res. Kafr ElSheikh Univ. 39: 37-53.

Abou- Kerisha, M. A., R. A. Gadallah and E. E. A. Mohamdain. 2008. Response of groundnut to intercropping with some sesame varieties under deferent plant density. Arab Uni. J. Agric. Sci., Ain shams Univ. Cairo. 16 (2):359 - 375.

Ali, M.H, M.R Hoqu, A.A.Hassan and A.Kair. 2007. Effect of deficit irrigation on yield, water productivity and economic returns of wheat Agricultural Management. 92 (3):151-161.
Anonymous. 2006. Adaption Research Recommendations. Agri. Dept., Govt. of the Punjab, Lahore, Pakistan

Badran, M.S. 2002. solid versus intercropping sesame with groundnut at different sequences of sowing dates. III. Competitive relations. Alex. J. Agric. Res. 47 (3): 31-39

. Banik, P., A. Midya, B. K. Sarker and S.S. Ghose. 2006. Wheat and chickpea Intercropping system in an additive series experiment. Advantages and weed smothering. Europ. J. Agron. 24: 325-332.

Bhatti, I.H, R. Ahmad, Abdul-Gabbar, M.S.Nazir and T.Mahmood. 2006. competitive behavior of component crops in different sesame legume intercropping systems. Int. J.Agric. \&Biol. 8(2): 165-167.

Chimanshette, T.G. and M.V.Dhoble. 1992. Effect sowing date and plant density on seed yield of sesame (sesamumindicum) varieties. Indian .J.Agron. 37 (2): 280282. 
Dhima.K.V, A.S.Lithourgidis, I.B.Vasilakoglou and C.A.D ordas. 2007. Competition indices of common vetch and cereal intercrops in two seeding ratio. Field Crops Research. 100 (2-3): 249-256.

El-Sawy, W.A., M.G.M.El-Baz and S.E.A.Toaima. 2006. Response of two peanut varieties to intercropping with sunflower under different sunflower sowing dates. Egypt. J.of Appl. Sci. 21 (3):193-210.

Ghosh, P.K. 2004. Growth, yield, competition and economic of groundnut /cereal fodder intercropping systems in the semi-arid tropics of India. Field Crops Res. 88: 217-237.

Gomez K.N and A.A. Gomez. 1984. Statistical procedures for Agricultural research. An international Rice research institute Book John Willey and Sons. New Yourk

Iqbal. J, Z. A. Cheema and M. An. 2007. Intercropping of field crops in cotton for the management of purple nutsedge (Cyperus rotundus L.) Plant Soil. 300:163-171

Hansen, V.W, O.W. Israelsen and Q.E. Stringharm. 1979.Irrigation principles and practices, 4 th ed. John Willey and Sons, New York.

Jackson, M. 1973. Soil Chemical Analysis. Prentice Hall of India private, LTD New Delhi.

Kassab, M. M. E. 2003. Towards effective water management for some field crops in North Nile Delta region. Ph.D. Thesis, Soil. Fac. of Agric. Moshtohor, Zagazig University (Benha Branch).

Klute, A.C. 1986. Water retention: Laboratory Methods. In: A. koute (ed.), Methods of Soil Analysis, part 1-2nd(ed.) Agron Monogr.9, ASA, Madison, W1 U.S.A, pp. 635-660.

Mahdy, A.Y. and M. A. A. El-Said. 2015. Response of sesame for intercropping with some forage crops. Minia J. of Agric. Res. \& Develop. 35 (1): 139-157.

Mead, R. and R.W. Willey. 1980. The concept of a land equivalent ratio and advantages in yield from intercropping. Exp. Agric. 16: 217-218.
Meleha, M. I. 2000. Effect of furrow length and methods of applying irrigation water on cotton yield and water use efficiency, J. Agric. Sci. Mansoura Univ. 25(3): 18831890.

Michael, A. M. 1978. Irrigation - Theory and practices. Vikas Publishing House, New Delhi.

Mohammad, B., A.Haboob and K.Abdul. 2001. Some Competition Functions and Economics of Different Cotton-Based Intercropping Systems. Int. J. Environ. Agric. Res. 4: 428-431.

Ofuso-Amin, J., N.V.Limbani. 2007. Effect of intercropping on the growth and yield of cucumber and okra.Int. J. Agric. Biol. 9(4): 594-597.

Raghuwanshi, R.K.S., R. Umat, A.K. Gupta and N.S. Gurjar. 1994. Performance of soybean-based intercropping systems in black cotton soils under different fertility levels. Crop Res. Hisar. 8: 233-8.

Rahnama, A. and A. Bakhshandeh. 2006. Determination of optimum row-spacing and plant density for unbranched sesame in Khuzestan province. J.Agric. Sci. Technol. 8: 25-33.

Raut, V.M., S.P. Taware and P. Varghere. 2000. Comparison of different sowing methods in soybean. J. of Moharashtra Agric. Univ. 25:218-219.

Shahid, M.R.M. and M. Saeed. 1997. Competitive relationship of component crops in different wheat-based intercropping systems. J. Anim. Pl. Sci. 7: 37-39.

Toaima,S.E.A, R.A. Atalla and W.A.El-Sawy. 2004. Response of same peanut genotypes to intercropping with sesame in relation to yield and yield components. Annuals of Agric. Sci. Moshtohor. 42 (3): 903-916.

Yilmaz, S., M.Atak, M.Erayman. 2007. Identification of advantages of maize-legume intercropping over solitary cropping through competition indices in the East Mediterranean Region.Turkey J. Agric. 16: 217-228.

Zhang, F.S., Li, L. 2003. Using competitive and facilitative interactions in intercropping systems enhances crop productivity and nutrient-use efficiency. Plant.Soil. 248: 305-312. 


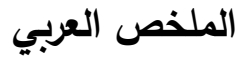 \\ تأثير مواعيد الزراعة والكثافة النباتيه للسمسم ونظام التحميل على المحصول ومكوناتة فى}

\section{القطن والسمسم}

مشيرة أحمد ابراهيم الثامى، منى عبدالحليم المنصورى ومها عبد الله البيلى

*تأثير مواعيد الزراعه كان غير معنوى على كل الصفات فى

القطن ماعدا محصول البذور /نبات فى الموسم التانى كان

معنوى فى حين كان محصول البذور /فدان معنوى فى كلا لإنا

الموسمين. بينما تأثير كان غير معنوى فى كل الصفات فى لئ فئ

السمسم ماعدا محصول البذور /نبات كان معنوى فى كلا

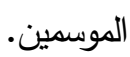

*تأثير الكثافة النباتيـه كـان معنوى وعـالى المعنويـه على كل

الصفات فى القطن ماعدا ارتفاع النبات فى كلا الموسمين

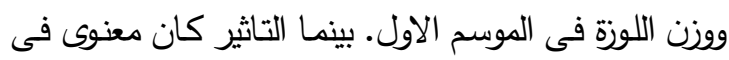

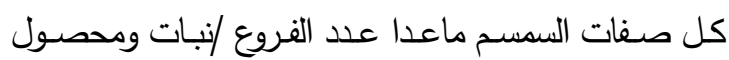

البذور /قفان كان غير معنوى فى كلا الموسمين.

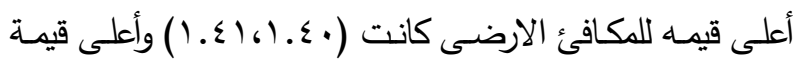

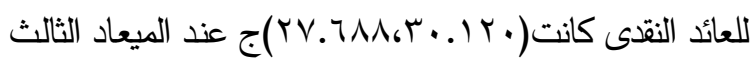

ققيمت تجربة حقليه بمحطة البحوث الزراعية بسخا- محافظة

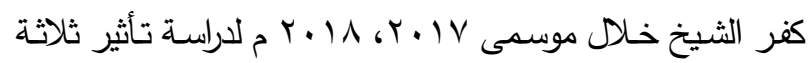

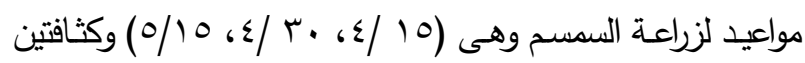
زراعة للسمس وهى (r \% \%، ـ0 \% \%) وكان التصميم الاحصائئ المستخدم هو القطع المنثقة مرة واحده فى ثلاثة مكرارات حيث يتم توزيـع مواعيد زراعـة السمسم فى القطع الرئيسيه وتوزيـع كثافات السمسم فى القطع الثقيه.

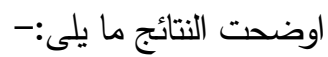

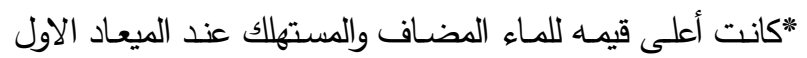

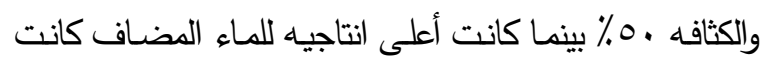

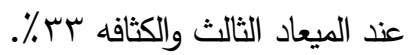

والكثافة سץ\%٪. 